\title{
Gastric Non-Neoplastic Polyp
}

National Cancer Institute

\section{Source}

National Cancer Institute. Gastric Non-Neoplastic Polyp. NCI Thesaurus. Code C95767.

A non-neoplastic polyp that arises from the stomach. This category includes hyperplastic polyps and hamartomatous polyps. 